might arise from the large number of fixed beacon stations now in operation for the use of ship directionfinders. Although these beacons are located in a restricted band of wave-lengths, it has proved possible to utilise different modulation note frequencies, and it is considered that as at present organised, mutual interference between beacon stations is negligible.

\section{Interference with Broadcast Reception}

THE problem of the elimination of the interference caused to broadcast reception by electrical machines and apparatus is of widespread interest and is being studied in many countries. A Conference has been held in Paris recently under the auspices of the Electrotechnical Commission, at which representatives of various international electrical and broadcasting organisations were present. A brief report of the results of this Conference is given in World Radio of July 13. It was agreed that no protection need be considered at the present time for the case of a wanted signal strength of less than 1 millivolt per metre, and that the interference should be considered relative to a signal carrier wave of this intensity, modulated to a mean depth of 20 per cent. Under these conditions it was considered desirable, if reception free from interference is to be obtained, that the level of the interference field should be $40 \mathrm{db}$. below that of the wanted signal. At the present time, it would appear to be difficult and premature to fix a definite, practical value applicable to electrical installations, until further experimental data on this aspect of the problem have been obtained.

ONE of the difficulties accompanying legislation in this subject is the interpretation of the results of measurements of interference obtained by different methcds. Three main methods are already in use in different countries for evaluating the relative magnitude of interference, these being known as the French, German and British methods respectively. At the Paris Conference it was agreed that a comparison of these three methods should be carried out in Berlin in October next by a group of five experts assisted by the General Secretary of the I.E.C., with the view of proposing that one of these or some alternative method should be adopted for international use. The British interests in this matter of interference reduction are safeguarded by the Radio Interference Committee of the Institution of Electrical Engineers in co-operation with the British Standards Institution, and these bodies were largely responsible for the success of the recent meeting in Paris.

\section{Congrès Préhistorique de France}

A cordial invitation to attend the eleventh Prehistoric Congress of France is extended to all archæologists by its president and officers. The Congress is to be held at Perigueux on September 16-22. A special interest is attached to this meeting of the Congress, as it was at Perigueux thirty years ago that the Congress met for the first time. It had been constituted in the previous year on the proposal of MM. Émile Rivière and Marcel Baudouin, by the then recently founded Société Préhistorique de France. Its meetings were interrupted by the War and were resumed in 1931. The present session will be the first since that date. Apart from its sentimental interest, the meeting is of importance as taking place in the heart of the classical territory of prehistoric study, in which the evidence for the art and industry of palæolithic man abounds. It is appropriate, therefore, that the Conseil Général of la Dordogne will join with the Municipality of Perigueux in offering a welcome to members of the Congress. The Congress will meet under the presidency of Dr. Felix Regnault. The honorary general secretary and treasurer is M. Charles Schleicher, treasurer of the Société Préhistorique. The arrangements are in the hands of a strong local committee. So far as at present arranged, the subjects to which special attention will be devoted in the communica. tions submitted to the Congress are the palæolithic period in the region of meeting, the mesolithic and neolithic of the Dordogne, and artificial caves and souterrains. The principal sites of interest in the area will be visited and excavations demonstrated in the course of the meeting. Notifications of desire to attend, subscriptions (Membre titulaire, $30 \mathrm{fr}$., Membre titulaire souscripteur, 100 fr., Membre adhérent, 20 fr.), communications, etc., should be addressed to M. Ch. Schleicher, 9, rue de Verneuil, Paris (vii ).

\section{Medical Aspects of Physical Culture}

AN International Congress of Medicine applied to Physical Education and Sport will be held at Chamonix on September 3-5 under the presidency of Prof. A. Carnot of Paris. It has been organised by Prof. A. Latarjet, of Lyons, president of the International Association of Sport Medicine, as the result of a Congress held at Turin in 1933. The Congress will consist of the following sections with their special presidents : Biology (Prof. H. Laugier), Medicine and Pædiatrics (Dr. Jules Renault), Surgery and Orthopædics (Prof. L. Rocher), Physical Education during and after the School Period (Prof. Chaillet-Bert), and Sport Medicine (Prof. Grégoire). The following questions will be discussed before the united sections : biometrical standardisation of sport, medical control of physical education and sport, and medical indications for treatment at high altitudes. The object of the Congress is to secure the co-operation of biologists, clinicians and sportsmen and to further the scientific and social development of physical education. Further details of the Congress will be published later. The general secretaries are Dr. Godlewski, 14 rue Théodule Ribot, Paris, and Prof. Cordier, 1 rue Childebert, Lyons. The regional secretary is Dr. Agnel, Chamonix.

\section{Faraday Society Discussion on Colloidal Electrolytes}

A PRELIminary programme is now available of the General Discussion on Colloidal Electrolytes to be held by the Faraday Society at University College, London, on September 27-29. Prof. H. Freundlich will deliver an introductory paper, and papers in the remaining sessions will be grouped according as they 